Full research paper Journal of Pharmacy and Pharmacology

\title{
Effect of instillation method on absorption of phenol red as a model from liver and small intestinal serosal surface in rats
}

Koyo Nishida, Yayoi Yoshida, Takahiro Mukai, Shigeru Kawakami, Toshiyuki Sakaeda, Mikiro Nakashima, Hitoshi Sasaki and Junzo Nakamura

School of Pharmaceutical Sciences, Nagasaki University, 1-14 Bunkyo-machi, Nagasaki 852-8521, Japan

K. Nishida, Y. Yoshida, T. Mukai, S. Kawakami, J. Nakamura

Department of Hospital Pharmacy, School of Medicine, Kobe University, 7-5-2

Kusunoki-cho, Chuo-ku, Kobe 650-0017, Japan

T. Sakaeda

Department of Hospital Pharmacy, Nagasaki University School of Medicine, 1-7-1

Sakamoto, Nagasaki 852-8501, Japan

M. Nakashima, H. Sasaki

Correspondence: K. Nishida, School of Pharmaceutical Sciences, Nagasaki University, 1-14 Bunkyo-machi, Nagasaki 852-8521, Japan.

Tel/Fax: +81-95-845-7218Ｅ-Mail: koyo-n@net.nagasaki-u.ac.jp

Shortened title: Effect of instillation method on absorption 


\section{Abstract}

The aim of this study is to examine the effect of the instillation method on absorption of a drug from the liver and small intestinal serosal surface in rats. We performed continuous microinstillation via an infusion pump and bolus instillation via a syringe. Phenol red as a model was absorbed after continuous microinstillation of $2.35 \mathrm{mg}$ in $235 \mu \mathrm{L}$ for $5 \mathrm{~min}$ on the liver and small intestinal serosal surface in rats with a significantly higher AUC of the plasma concentration profile until $60 \mathrm{~min}$, compared with that after bolus instillation. A similar trend was observed after continuous microinstillation of $2.35 \mathrm{mg}$ in $117.5 \mu \mathrm{L}$ for $2.5 \mathrm{~min}$. The calculated absorption rate constants $\mathrm{K}_{\mathrm{a}}$ after continuous microinstillation of phenol red based on a two-compartment model with first-order absorption were higher than those after bolus instillation on the liver and small intestinal serosal surface at either instillation concentration. Moreover, $\mathrm{K}_{\mathrm{a}}$ was increased after continuous microinstillation of $2.35 \mathrm{mg}$ in $117.5 \mu \mathrm{L}$ on either instillation site. In the comparison between instillation sites, instillation of phenol red on the liver surface resulted in 1.2 to 2.3 -fold higher $\mathrm{K}_{\mathrm{a}}$, compared to small intestinal serosal surface. This tendency was marked after continuous microinstillation of $2.35 \mathrm{mg}$ in $117.5 \mu \mathrm{L}$. In conclusion, absorption could be enhanced by instilling a small amount of drug solution on the liver surface gradually and continuously, suggesting a promising approach for instillation site-selective drug delivery in the peritoneal cavity. 


\section{Introduction}

The intraperitoneal (ip) administration method has been used for application of anticancer drugs that are difficult for oral administration. For ip administration to liver cancer chemotherapy, the drug solution after ip administration is expected to distribute preferentially around the diseased region in the liver. Although iv, hepatic arterial and portal administration have been attempted as targeted delivery methods (Anderson et al 1994), the administered drug tends to distribute through the entire liver. We have previously shown that direct injection into an organ is not suitable for site-selective drug delivery to the liver with a high blood flow, since directly injected drugs are rapidly cleared from the injection site and enter the systemic circulation (Nishida et al 1994). Therefore, it was suggested that instillation of a small amount of drug solution continuously should be effective to keep a high concentration of drug around the liver surface. Recently, implantable infusion pumps have been developed for treatment of several diseases (Hepp 1994), and endoscopic and laparoscopic operation techniques have been markedly improved (Stellato 1992). These advanced medical technologies should make possible the clinical use of continuous microinstillation of drugs on the liver surface and other regions in the peritoneal cavity.

After instillation of drug solution on the liver surface, drugs are believed to spread throughout the peritoneal cavity and to be diluted by serous fluid and ascites, leading to a reduction of drug accumulation around the instillation site. Therefore, we examined the effect of the instillation method on the absorption characteristics from the liver surface and compared it with that after instillation on the small intestinal serosal surface in the peritoneal cavity. In addition, we studied the influence of the instillation drug concentration and volume on the absorption rate. In this study, we selected phenol red as a model drug, because its absorption mechanism from the liver surface in rats has been clarified (Nishida et al 1995a). Phenol red, a hydrophilic dye (organic anion), has been clinically used as a renal 
function test compound in humans, and is excreted into bile and urine as a free form or conjugative metabolite in rats (Hart \& Schanker 1966). 


\section{Materials and Methods}

\section{Animal study}

All animal experiments in the present study conformed to the Guideline for Animal Experimentation in Nagasaki University. Male Wistar rats (230-270 g), which were not starved, were anaesthetized with sodium pentobarbitone (50 $\mathrm{mg} \mathrm{kg}^{-1}$ body weight, intramuscular injection), and an incision was made in the middle abdomen. The left femoral artery and common bile duct were cannulated with a polyethylene tube. Additional sodium pentobarbitone was administered as necessary during the experiment to maintain anaesthesia. Phenol red (Nacalai Tesque, Inc., Kyoto, Japan) solution was prepared in isotonic phosphate buffer ( $\mathrm{pH}$ 7.4) to yield a concentration of 10 or $20 \mathrm{mg} \mathrm{mL}^{-1}$, and administered as follows. A schematic diagram of the instillation method is shown in Figure 1.

Continuous microinstillation on the liver or small intestinal serosal surface: The phenol red solution (20 mg mL ${ }^{-1}$ X $117.5 \mu \mathrm{L}$ or $10 \mathrm{mg} \mathrm{mL}^{-1}$ X $235 \mu \mathrm{L}$ ) was instilled using a polyethylene tube fixed by a clamp on the surface of the left lateral liver lobe or distal small intestine with an infusion pump (flow rate $0.047 \mathrm{~mL} \mathrm{~min}^{-1}$ ) (Natsume, Tokyo, Japan) for 2.5 and 5 min, respectively.

Bolus instillation on the liver or small intestinal serosal surface: The phenol red solution (20 mg mL ${ }^{-1}$ X $117.5 \mu \mathrm{L}$ or $10 \mathrm{mg} \mathrm{mL}^{-1}$ X $235 \mu \mathrm{L}$ ) was instilled momentarily on the surface of the left lateral lobe or distal small intestine using a syringe.

After instillation of phenol red solution, $200 \mu \mathrm{L}$ blood was collected for 12 times at 2, 5, 10, 15, 30, 60, 90, 120, 150, 180, 210 and $240 \mathrm{~min}$ from the heparinized cannula inserted into the femoral artery for $4 \mathrm{~h}$. Blood was centrifuged at 15,000 rev min $^{-1}$ for 5 min. Bile samples were collected at appropriate time intervals for $4 \mathrm{~h}$. At $4 \mathrm{~h}$ after instillation, the 
solution remaining in the peritoneal cavity was withdrawn by washing with saline.

The concentration of free phenol red was determined spectrophotometrically at $560 \mathrm{~nm}$ after dilution with $1 \mathrm{M} \mathrm{NaOH}$. The total concentration of free phenol red and its conjugative metabolite (glucuronic acid conjugate) was measured in the same manner after the samples were subjected to acid hydrolysis $\left(1 \mathrm{M} \mathrm{HCl}\right.$ at $100^{\circ} \mathrm{C}$ for $30 \mathrm{~min}$ ) (Hart \& Schanker 1966). The concentration of phenol red metabolite was estimated from the difference between these values. The phenol red metabolite could not be detected in the plasma.

\section{Pharmacokinetic analysis with a compartment model}

Compartment model analysis of the plasma concentration profile of phenol red after bolus instillation or continuous microinstillation on the liver or small intestinal serosal surface in rats was performed based on a two-compartment model with first-order absorption as follows by the nonlinear least-squares method (Yamaoka et al 1981). The pharmacokinetic models are illustrated in Figures 2A and 2B.

Bolus instillation: The equation for concentration of central compartment $\left(\mathrm{C}_{1}\right)$ after bolus instillation is based on the model as shown in Figure 2B.

$$
C_{1}=\frac{F \cdot D \cdot K_{a}}{V_{c}}\left\{\frac{K_{21}-K_{a}}{\left(\beta-K_{a}\right)\left(\alpha-K_{a}\right)} e^{-K_{a} \cdot t}+\frac{K_{21}-\alpha}{(\beta-\alpha)\left(K_{a}-\alpha\right)} e^{-\alpha \cdot t}+\frac{K_{21}-\beta}{(\alpha-\beta)\left(K_{a}-\beta\right)} e^{-\beta \cdot t}\right\}
$$

Hybrid parameters $\alpha$ and $\beta$ are defined as $\alpha+\beta=\mathrm{K}_{12}+\mathrm{K}_{21}+\mathrm{K}_{\mathrm{el}}$ and $\alpha \cdot \beta=\mathrm{K}_{21} \cdot \mathrm{K}_{\mathrm{el}} . \quad \mathrm{V}_{\mathrm{c}}$ is the volume of the central compartment. $\quad \mathrm{K}_{\mathrm{el}}$ is the first-order elimination rate constant from the central compartment. $\quad \mathrm{K}_{12}$ and $\mathrm{K}_{21}$ are the first-order transfer rate constants between the central and peripheral compartment. $\quad \mathrm{K}_{\mathrm{a}}$ is the first-order absorption rate constant for absorption into the blood stream from the liver or small intestinal serosal surface. D is the instilled dose, and $\mathrm{F}$ is the availability after instillation. The result for i.v. administration of phenol red was reported previously (Nishida et al 1995a). 
Continuous microinstillation: In continuous microinstillation, we first analyzed the plasma concentration profile after the end of instillation $\left(\mathrm{t}_{0}\right)$ with a two-compartment model as shown in Figure 2B according to equation 3 by the nonlinear least-squares method (Yamaoka et al 1981). In equation $3, \mathrm{X}_{\mathrm{ip}}(0)$ is the drug amount in intraperitoneal compartment at the end of instillation $\left(\mathrm{t}_{0}\right) . \quad \mathrm{C}_{1}(0)$ and $\mathrm{C}_{2}(0)$ are concentrations of central and peripheral compartment at the end of instillation ( $\left.\mathrm{t}_{0}\right)$, respectively. After obtaining the pharmacokinetic parameters ( $\mathrm{K}_{\mathrm{a}}$ and $\left.\mathrm{F}\right)$, the plasma concentration profile before the end of instillation ( $\mathrm{t}<\mathrm{t}_{0}$ ) was simulated according to equation 4 . In equation $4, \mathrm{~K}_{0}$ is the drug instillation rate.

(i) $\mathrm{t} \geqq \mathrm{t}_{0}:$

$$
\begin{aligned}
\mathrm{C}_{1} & =\frac{\mathrm{F} \cdot \mathrm{K}_{\mathrm{a}} \cdot \mathrm{X}_{\mathrm{ip}}(0)}{\mathrm{V}_{\mathrm{c}}}\left\{\frac{\mathrm{K}_{21}-\mathrm{K}_{\mathrm{a}}}{\left(\beta-\mathrm{K}_{\mathrm{a}}\right)\left(\alpha-\mathrm{K}_{\mathrm{a}}\right)} \mathrm{e}^{-\mathrm{K}_{\mathrm{a}}\left(\mathrm{t}-\mathrm{t}_{0}\right)}+\frac{\mathrm{K}_{21}-\alpha}{(\beta-\alpha)\left(\mathrm{K}_{\mathrm{a}}-\alpha\right)} \mathrm{e}^{-\alpha\left(\mathrm{t}-\mathrm{t}_{0}\right)}+\frac{\mathrm{K}_{21}-\beta}{(\alpha-\beta)\left(\mathrm{K}_{\mathrm{a}}-\beta\right)} \mathrm{e}^{-\beta\left(\mathrm{t}-\mathrm{t}_{0}\right)}\right\} \\
& +\mathrm{C}_{1}(0)\left\{\frac{\mathrm{K}_{21}-\alpha}{\beta-\alpha} \mathrm{e}^{-\alpha\left(\mathrm{t}-\mathrm{t}_{0}\right)}+\frac{\mathrm{K}_{21}-\beta}{\alpha-\beta} \mathrm{e}^{-\beta\left(\mathrm{t}-\mathrm{t}_{0}\right)}\right\}+\frac{\mathrm{C}_{2}(0) \cdot \mathrm{K}_{21}}{\beta-\alpha}\left\{\mathrm{e}^{-\alpha\left(\mathrm{t}-\mathrm{t}_{0}\right)}-\mathrm{e}^{-\beta\left(\mathrm{t}-\mathrm{t}_{0}\right)}\right\}
\end{aligned}
$$

(ii) $\mathrm{t}<\mathrm{t}_{0}$

$$
\begin{aligned}
\mathrm{C}_{1}= & \frac{\mathrm{F} \cdot \mathrm{K}_{0} \cdot \mathrm{K}_{\mathrm{a}}}{\mathrm{V}_{\mathrm{c}}}\left\{\frac{\mathrm{K}_{21}}{\mathrm{~K}_{\mathrm{a}} \cdot \alpha \cdot \beta}+\frac{\mathrm{K}_{\mathrm{a}}-\mathrm{K}_{21}}{\mathrm{~K}_{\mathrm{a}}\left(\beta-\mathrm{K}_{\mathrm{a}}\right)\left(\alpha-\mathrm{K}_{\mathrm{a}}\right)} \mathrm{e}^{-\mathrm{K}_{\mathrm{a}} \cdot \mathrm{t}}+\frac{\alpha-\mathrm{K}_{21}}{\alpha(\beta-\alpha)\left(\mathrm{K}_{\mathrm{a}}-\alpha\right)} \mathrm{e}^{-\alpha \cdot \mathrm{t}}\right. \\
& \left.+\frac{\beta-\mathrm{K}_{21}}{\beta(\alpha-\beta)\left(\mathrm{K}_{\mathrm{a}}-\beta\right)} \mathrm{e}^{-\beta \cdot \mathrm{t}}\right\}
\end{aligned}
$$

\section{Statistical analysis}

Statistical analysis was performed by applying unpaired Student's $t$-test. $\quad P<0.05$ was considered to be statistically significant. All values were expressed as the mean value \pm standard error of at least four experiments. 


\section{Results and Discussion}

\section{Effect of the instillation method on the absorption of phenol red from the liver and small intestinal serosal surface}

We performed continuous microinstillation via an infusion pump and bolus instillation via a syringe of $2.35 \mathrm{mg}$ in 235 or $117.5 \mu \mathrm{L}$ of phenol red solution on the liver and small intestinal serosal surface in rats. The plasma concentration profiles of phenol red are shown in Figures 3A and 3B in a solution of $2.35 \mathrm{mg}$ in $235 \mu \mathrm{L}$. The plasma concentrations of phenol red after continuous microinstillation of $2.35 \mathrm{mg}$ in $235 \mu \mathrm{L}$ for $5 \mathrm{~min}$ on the liver and small intestinal serosal surface are higher in the first 60 min than those after bolus instillation. In addition, the maximum plasma concentration was increased by 1.5- or 1.3-fold after continuous microinstillation on the liver and small intestinal serosal surface, respectively, compared with bolus instillation (Figures 3A and 3B).

Figures 4A and 4B show similar findings for instillation of phenol red solution of 2.35 mg in $117.5 \mu \mathrm{L}$. A similar tendency of higher maximum concentration was observed in the plasma concentration profiles of phenol red after continuous microinstillation of $2.35 \mathrm{mg}$ in $117.5 \mu \mathrm{L}$ for 2.5 min, compared with bolus instillation (Figures 4A and 4B). Accordingly, an increase in the absorption of phenol red was suggested by continuous microinstillation.

Table 1 summarizes the recovery ratio in the peritoneal cavity, and biliary and urinary excretion ratios of phenol red at $4 \mathrm{~h}$ after instillation on the liver or small intestinal serosal surface under different instillation conditions. Since the absorption from the peritoneal cavity was almost completed in $4 \mathrm{~h}$, the recovery ratios of phenol red from the peritoneal cavity were less than $3 \%$ of the dose. The total biliary excretion ratio after $4 \mathrm{~h}$ of phenol red bolus instillation was higher than that after continuous microinstillation, while the urinary excretion ratio after continuous microinstillation was higher, although the difference was not significant. The difference in the biliary and urinary excretion ratios of phenol red might 
be considered to be alterations in the absorption route after continuous microinstillation and bolus instillation.

\section{Pharmacokinetic analysis of the plasma concentration profiles of phenol red}

AUC of the plasma concentration profile of phenol red $\left(\mathrm{AUC}_{\mathrm{p}}\right)$ was calculated until 10, 15, 30, 60 and 240 min to examine time course of the absorption rate of phenol red, as shown in Table 2. Continuous microinstillation on the liver and small intestinal serosal surface exhibited higher $\mathrm{AUC}_{\mathrm{p}}$ values of phenol red until 60 min after instillation compared with those after bolus instillation at either concentration, even though no difference was observed in $\mathrm{AUC}_{\mathrm{p}}$ values until 240 min. This indicates increased absorption from the liver and small intestinal serosal surface by continuous microinstillation. In addition, the trend was marked in continuous microinstillation on the liver, compared to small intestinal serosal surface.

Moreover, the plasma concentration profiles of phenol red were analyzed based on a compartment model as illustrated in Figures 2A and 2B, assuming that the absorption process after continuous microinstillation and bolus instillation follows first-order kinetics. In case of continuous microinstillation, the plasma concentration profile during drug instillation $(\mathrm{t}<$ $\mathrm{t}_{0}$ ) was simulated based on Model A (Figure 2A) using the $\mathrm{K}_{\mathrm{a}}$ value obtained with the model fitting of the plasma concentration profile after drug instillation $\left(\mathrm{t} \geqq \mathrm{t}_{0}\right)$ based on the pharmacokinetic model shown in Figure 2B. Figures 3 and 4 show the fitting curves under different instillation conditions. In general, they agreed well with the experimental values and, therefore, the validity of this compartment model analysis was confirmed. The deviation between the experimental and fitted values was observed in some data series (figures 3 and 4), due to the curve fitting procedure (nonlinear least square regression).

The $K_{a}$ values of phenol red under different conditions are listed in Table $2 . \quad$ In the comparison of identical instillation sites, the $\mathrm{K}_{\mathrm{a}}$ values of phenol red after continuous microinstillation were larger than those after bolus instillation, supporting the improvement of 
absorbability by continuous microinstillation. In addition, the $\mathrm{K}_{\mathrm{a}}$ of phenol red was increased by 1.4 to 2.6 -fold by reducing the instillation volume from 235 to $117.5 \mu \mathrm{L}$ as shown in Table 2. This finding is consistent with our observation that the $\mathrm{K}_{\mathrm{a}}$ of phenol red after ip administration to the rat liver surface increased with decreasing application volume (Nishida et al 1997).

\section{Influence of the instillation site on the absorption rate of phenol red}

The pharmacokinetic analysis suggested that continuous microinstillation of phenol red resulted in faster absorption from the peritoneal cavity. This tendency was significant after continuous microinstillation of $2.35 \mathrm{mg}$ in $117.5 \mu \mathrm{L}$ for $2.5 \mathrm{~min}$ on the liver surface, when it was about 3-fold higher $\mathrm{K}_{\mathrm{a}}$ compared with bolus instillation (Table 2). $\quad$ On the other hand, when comparing $\mathrm{K}_{\mathrm{a}}$ at identical instillation volumes, the instillation of phenol red on the liver surface increased $\mathrm{K}_{\mathrm{a}}$ by 1.2 to 2.3 -fold compared with instillation on the small intestinal serosal surface. We previously reported that the absorption rate from the peritoneal cavity was faster after ip administration on the liver surface than that after ip administration on the distal small intestinal serosal surface, as shown by the increase in the maximum concentration and the decrease in the mean residence time of phenol red in plasma (Nishida et al 1995b).

When drugs are instilled continuously, it appears that the drug concentration at the instillation site can be maintained because of the restricted distribution compared with bolus instillation. In a previous study, the concentration of phenol red at the instillation site in the liver (left lateral lobe) was significantly higher than that at the other lobes of the liver after continuous microinstillation (Nakamura et al 1999). However, when the same volume of drug solution was instilled on the small intestine or injected intravenously, no significant difference in drug concentration between the left lateral and other lobes was found, suggesting a uniform distribution of phenol red in the liver (Nakamura et al 1999).

In conclusion, a good absorption of phenol red from the instilled site of the liver was 
attained by continuous microinstillation, possibly leading to restricted drug distribution in the liver. Further information should be clarified for clinical relevance in the future.

\section{Acknowledgements and funding:}

We thank Miyuki Ando for skilled technical assistance. This work was supported in part by a Grant-in-Aid for Scientific Research from the Ministry of Education, Culture, Sports, Science and Technology, Japan. 


\section{References}

Anderson, J. H., Warren, H. W., McArdle, C. S. (1994) Clinical pharmacokinetic advantages of new drug delivery methods for the treatment of liver tumours. Clin. Pharmacokinet. 27: $191-201$

Hart, L. G., Schanker, L. S. (1966) The chemical forms in which phenol red is secreted into the bile of rats. Proc. Soc. Exp. Biol. Med. 123: 433-435

Hepp, K. D. (1994) Implantable insulin pumps and metabolic control. Diabetologia 37: S108-S111

Nakamura, J., Yoshida, Y., Mera, K., Mukai, T., Nishida, K., Sasaki, H. (1999) Continuous microinstillation of phenol red on liver surface for liver site-selective delivery. Biol. Pharm. Bull. 22: 713-715

Nishida, K., Sato, N., Sasaki, H., Nakamura, J. (1994) Absorption of organic anions as model drugs following application to rat liver surface in-vivo. J. Pharm. Pharmacol. 46: 867-870

Nishida, K., Sato, N., Sasaki, H., Nakamura, J. (1995a) Mechanism for drug absorption from rat-liver surface membrane: Effect of dose and transport inhibitors on the pharmacokinetics of phenol red. J. Pharm. Pharmacol. 47: 227-231

Nishida, K., Amagishi, H., Sasaki, H., Nakamura, J. (1995b) Absorption of phenol red and bromphenol blue as model drugs from the peritoneal cavity around the liver surface in rats. J. Pharm. Pharmacol. 47: 1032-1035

Nishida, K., Sato, N., Nakakoga, Y., Mukai, T., Sasaki, H., Nakamura, J. (1997) Effect of application volume and area on the absorption of phenol red, as a model drug, from the liver surface in rats. J. Pharm. Pharmacol. 49: 976-980

Stellato, T. A. (1992) History of laparoscopic surgery. Surg. Clin. North Am. 72: 997-1002 Yamaoka, K., Tanigawara, Y., Nakagawa, T., Uno, T. (1981) A pharmacokinetic analysis program (MULTI) for microcomputer. J. Pharmacobio-Dyn. 4: 879-885 


\section{Figure captions}

Figure 1 Experimental method for drug instillation on the liver surface (left lobe) or small intestinal serosal surface in rats.

Figure 2 Pharmacokinetic model for phenol red after continuous microinstillation or bolus instillation. (Model A) $\mathrm{t}<\mathrm{t}_{0}$, continuous microinstillation during drug instillation (Model $\mathrm{B}$ ) $\mathrm{t} \geqq \mathrm{t}_{0}$, continuous microinstillation or bolus instillation

$\mathrm{X}_{\mathrm{ip}}$, Amount in intraperitoneal compartment; $\mathrm{C}_{1}$, Concentration of central compartment; $\mathrm{C}_{2}$, Concentration of peripheral compartment; $\mathrm{K}_{0}$, Instillation rate; $\mathrm{K}_{\mathrm{a}}$, First-order absorption rate constant; $\mathrm{K}_{\mathrm{el}}$, First-order elimination rate constant; $\mathrm{K}_{12}, \mathrm{~K}_{21}$, First-order transfer rate constant; $\mathrm{V}_{\mathrm{c}}$, Volume of central compartment; $\mathrm{V}_{\mathrm{p}}$, Volume of peripheral compartment Figure 3 Plasma concentration profiles of phenol red after continuous microinstillation for $5 \mathrm{~min}$ at a flow rate of $0.047 \mathrm{~mL} \mathrm{~min}^{-1}$ (closed circle) or bolus instillation (open circle) of $2.35 \mathrm{mg}$ in $235 \mu \mathrm{L}$ on the liver or small intestinal serosal surface in rats. Curves show the simulated function based on the pharmacokinetic parameters listed in Table 2. Each point represents the mean \pm s.e. of at least four experiments. Significantly different from the result after bolus instillation $\left(* P<0.05\right.$, $\left.{ }^{* *} P<0.01\right)$.

Figure 4 Plasma concentration profiles of phenol red after continuous microinstillation for $2.5 \mathrm{~min}$ at a flow rate of $0.047 \mathrm{~mL} \mathrm{~min}^{-1}$ (closed circle) or bolus instillation (open circle) of $2.35 \mathrm{mg}$ in $117.5 \mu \mathrm{L}$ on the liver or small intestinal serosal surface in rats. Curves show the simulated function based on the pharmacokinetic parameters listed in Table 2. Each point represents the mean \pm s.e. of at least four experiments. Significantly different from the result after bolus instillation $(* * P<0.01)$. 
Table 1 Recovery (\% of dose) after $4 \mathrm{~h}$ of phenol red continuous microinstillation or bolus instillation on the liver or small intestinal serosal surface in rats.

\begin{tabular}{|c|c|c|c|c|c|c|c|c|}
\hline \multirow[t]{2}{*}{ Site } & \multirow[t]{2}{*}{ Method } & \multirow{2}{*}{$\begin{array}{l}\text { Peritoneal } \\
\text { cavity }\end{array}$} & \multicolumn{3}{|c|}{ Bile } & \multicolumn{2}{|c|}{ Urine } & \multirow[b]{2}{*}{ Total } \\
\hline & & & Free & Metabolite & Total & Free & Metabolite & \\
\hline \multicolumn{9}{|c|}{$2.35 \mathrm{mg}$ in $235 \mu \mathrm{L}$} \\
\hline \multirow[t]{2}{*}{ Liver } & $\begin{array}{l}\text { Continuous } \\
\text { (5 min) }\end{array}$ & $\begin{array}{r}1.9 \\
\pm 0.6\end{array}$ & $\begin{array}{r}25.2 \\
\pm 4.7\end{array}$ & $\begin{array}{r}13.8 \\
\pm 1.4\end{array}$ & $\begin{array}{r}39.0 \\
\pm 5.6\end{array}$ & $\begin{array}{r}30.8 \\
\pm 4.3\end{array}$ & $\begin{array}{r}9.0 \\
+1.7\end{array}$ & $\begin{array}{r}39.8 \\
\pm 5.8\end{array}$ \\
\hline & Bolus & $\begin{array}{r}1.7 \\
\pm 0.3\end{array}$ & $\begin{array}{r}33.6 \\
\pm 2.3\end{array}$ & $\begin{array}{r}10.1 \\
\pm 2.9\end{array}$ & $\begin{array}{r}43.7 \\
\pm 4.5\end{array}$ & $\begin{array}{r}20.7 \\
\pm 3.7\end{array}$ & $\begin{array}{r}4.8 \\
+1.3\end{array}$ & $\begin{array}{r}25.5 \\
\pm 3.1\end{array}$ \\
\hline \multirow[t]{2}{*}{$\begin{array}{l}\text { Small } \\
\text { intestine }\end{array}$} & $\begin{array}{l}\text { Continuous } \\
(5 \mathrm{~min})\end{array}$ & $\begin{array}{r}1.4 \\
\pm 0.5\end{array}$ & $\begin{array}{r}26.4 \\
\pm 4.9\end{array}$ & $\begin{array}{r}16.6 \\
\pm 2.4\end{array}$ & $\begin{array}{r}43.0 \\
\pm 7.2\end{array}$ & $\begin{array}{r}34.2 \\
\pm 5.7\end{array}$ & $\begin{array}{r}5.7 \\
+1.2\end{array}$ & $\begin{array}{r}39.9 \\
\pm 5.5\end{array}$ \\
\hline & Bolus & $\begin{array}{r}2.7 \\
\pm 0.8\end{array}$ & $\begin{array}{r}32.5 \\
\pm 5.3\end{array}$ & $\begin{array}{r}16.0 \\
\pm 3.2\end{array}$ & $\begin{array}{r}48.5 \\
\pm 7.9\end{array}$ & $\begin{array}{r}20.3 \\
\pm 3.0\end{array}$ & $\begin{array}{r}6.1 \\
+1.8\end{array}$ & $\begin{array}{r}26.4 \\
\pm 4.5\end{array}$ \\
\hline \multicolumn{9}{|c|}{$2.35 \mathrm{mg}$ in $117.5 \mu \mathrm{L}$} \\
\hline \multirow[t]{2}{*}{ Liver } & $\begin{array}{l}\text { Continuous } \\
\text { (2.5 min) }\end{array}$ & $\begin{array}{r}1.4 \\
\pm 0.6\end{array}$ & $\begin{array}{r}24.4 \\
\pm 5.0\end{array}$ & $\begin{array}{r}12.0 \\
\pm 3.0\end{array}$ & $\begin{array}{r}36.4 \\
\pm 6.9\end{array}$ & $\begin{array}{r}35.4 \\
\pm 4.6\end{array}$ & $\begin{array}{r}5.2 \\
\pm 0.7\end{array}$ & $\begin{array}{r}40.6 \\
\pm 4.7\end{array}$ \\
\hline & Bolus & $\begin{array}{r}2.0 \\
\pm 0.2\end{array}$ & $\begin{array}{r}35.8 \\
\pm 4.4\end{array}$ & $\begin{array}{r}12.1 \\
\pm 3.1\end{array}$ & $\begin{array}{r}47.9 \\
\pm 4.1\end{array}$ & $\begin{array}{r}24.9 \\
\pm 2.0\end{array}$ & $\begin{array}{r}4.5 \\
\pm 0.9\end{array}$ & $\begin{array}{r}29.4 \\
\pm 1.7\end{array}$ \\
\hline \multirow[t]{2}{*}{$\begin{array}{l}\text { Small } \\
\text { intestine }\end{array}$} & $\begin{array}{l}\text { Continuous } \\
\text { (2.5 min) }\end{array}$ & $\begin{array}{r}1.5 \\
\pm 0.3\end{array}$ & $\begin{array}{r}32.6 \\
\pm 3.7\end{array}$ & $\begin{array}{r}15.2 \\
\pm 2.2\end{array}$ & $\begin{array}{r}47.8 \\
\pm 4.6\end{array}$ & $\begin{array}{r}37.8 \\
\pm 3.2\end{array}$ & $\begin{array}{r}4.3 \\
+1.2\end{array}$ & $\begin{array}{r}42.1 \\
\pm 3.8\end{array}$ \\
\hline & Bolus & $\begin{array}{r}2.2 \\
\pm 0.2\end{array}$ & $\begin{array}{r}35.6 \\
\pm 1.0\end{array}$ & $\begin{array}{r}16.0 \\
\pm 1.8\end{array}$ & $\begin{array}{l}51.6 \\
\pm 2.0\end{array}$ & $\begin{array}{r}28.0 \\
\pm 3.0\end{array}$ & $\begin{array}{r}6.1 \\
\pm 1.8\end{array}$ & $\begin{array}{r}34.1 \\
\pm 4.5\end{array}$ \\
\hline
\end{tabular}

Each value is the mean \pm s.e. of at least four experiments. 
Table $2 \quad \mathrm{AUC}_{\mathrm{p}}$ and $\mathrm{K}_{\mathrm{a}}$ of phenol red after continuous microinstillation or bolus instillation on the liver or small intestinal serosal surface in rats.

\begin{tabular}{|c|c|c|c|c|c|c|c|}
\hline \multirow[t]{2}{*}{ Site } & \multirow[t]{2}{*}{ Method } & \multicolumn{5}{|c|}{$A \cup C_{p}\left(\mu g L^{-1} \min \right)$} & \multirow{2}{*}{$\begin{array}{c}\mathrm{K}_{\mathrm{a}} \\
\left(\min ^{-1} \times 10^{-2}\right)\end{array}$} \\
\hline & & $0-10$ & $0-15$ & $0-30$ & $0-60$ & $0-240$ & \\
\hline \multicolumn{8}{|c|}{$2.35 \mathrm{mg}$ in $235 \mu \mathrm{L}$} \\
\hline \multirow[t]{2}{*}{ Liver } & $\begin{array}{l}\text { Continuous } \\
\text { (5 min) }\end{array}$ & $\begin{array}{l}103.5^{*} \\
\pm 4.5\end{array}$ & $\begin{array}{l}204.6^{* *} \\
\pm 8.9\end{array}$ & $\begin{array}{l}502.8^{* *} \\
\pm 23.9\end{array}$ & $\begin{array}{c}978.4^{*} \\
\pm 45.5\end{array}$ & $\begin{array}{r}1920.9 \\
\pm 135.7\end{array}$ & $\begin{aligned} & 7.41^{* *} \\
\pm & 0.45\end{aligned}$ \\
\hline & Bolus & $\begin{array}{r}80.8 \\
\pm 9.4\end{array}$ & $\begin{array}{r}142.7 \\
\pm 15.7\end{array}$ & $\begin{array}{r}344.8 \\
\pm 34.1\end{array}$ & $\begin{array}{r}728.2 \\
\pm 69.2\end{array}$ & $\begin{array}{r}1714.7 \\
\pm 215.3\end{array}$ & $\begin{array}{r}4.00 \\
\pm 0.60\end{array}$ \\
\hline \multirow[t]{2}{*}{$\begin{array}{l}\text { Small } \\
\text { intestine }\end{array}$} & $\begin{array}{l}\text { Continuous } \\
\text { (5 min) }\end{array}$ & $\begin{array}{r}64.6 \\
\pm 4.6\end{array}$ & $\begin{array}{r}138.7 \\
\pm 10.1\end{array}$ & $\begin{array}{l}387.8^{*} \\
\pm 23.6\end{array}$ & $\begin{array}{l}880.8^{*} \\
\pm 44.1\end{array}$ & $\begin{array}{r}2038.7 \\
\pm 146.8\end{array}$ & $\begin{array}{r}3.93 \\
\pm 0.48\end{array}$ \\
\hline & Bolus & $\begin{array}{r}58.3 \\
\pm 4.3\end{array}$ & $\begin{array}{r}111.2 \\
\pm 7.8\end{array}$ & $\begin{array}{r}294.8 \\
\pm 20.3\end{array}$ & $\begin{array}{r}651.4 \\
\pm 49.0\end{array}$ & $\begin{array}{r}1573.3 \\
\pm 168.7\end{array}$ & $\begin{array}{r}3.24 \\
\pm 0.23\end{array}$ \\
\hline \multicolumn{8}{|c|}{$2.35 \mathrm{mg}$ in $117.5 \mu \mathrm{L}$} \\
\hline \multirow[t]{2}{*}{ Liver } & $\begin{array}{l}\text { Continuous } \\
\text { (2.5 min) }\end{array}$ & $\begin{array}{l}152.7^{* *} \\
\pm 4.8\end{array}$ & $\begin{array}{c}257.6^{* *} \\
\pm 6.5\end{array}$ & $\begin{array}{l}521.6^{* *} \\
\pm 13.7\end{array}$ & $\begin{array}{r}870.0 \\
\pm 43.0\end{array}$ & $\begin{array}{r}1436.0 \\
\pm 145.8\end{array}$ & $\begin{array}{l}19.35^{* * *} \\
\pm 2.35\end{array}$ \\
\hline & Bolus & $\begin{array}{r}103.0 \\
\pm 2.2\end{array}$ & $\begin{array}{r}175.2 \\
\pm 4.2\end{array}$ & $\begin{array}{r}387.6 \\
\pm 12.3\end{array}$ & $\begin{array}{r}751.4 \\
\pm 30.4\end{array}$ & $\begin{array}{r}1669.0 \\
\pm 78.8\end{array}$ & $\begin{array}{r}6.28 \\
\pm 0.59\end{array}$ \\
\hline \multirow[t]{2}{*}{$\begin{array}{l}\text { Small } \\
\text { intestine }\end{array}$} & $\begin{array}{l}\text { Continuous } \\
\text { (2.5 min) }\end{array}$ & $\begin{array}{r}109.7 \\
\pm 11.2\end{array}$ & $\begin{array}{r}210.6 \\
\pm 21.5\end{array}$ & $\begin{array}{r}510.4 \\
\pm 51.3\end{array}$ & $\begin{array}{r}971.0 \\
\pm 91.2\end{array}$ & $\begin{array}{r}1766.4 \\
\pm 156.0\end{array}$ & $\begin{array}{l}8.38^{*} \\
\pm 1.10\end{array}$ \\
\hline & Bolus & $\begin{array}{r}88.9 \\
\pm 8.0\end{array}$ & $\begin{array}{r}165.5 \\
\pm 13.6\end{array}$ & $\begin{array}{r}415.8 \\
\pm 26.0\end{array}$ & $\begin{array}{r}860.3 \\
\pm 47.1\end{array}$ & $\begin{array}{r}1909.2 \\
\pm 110.6\end{array}$ & $\begin{array}{r}4.44 \\
\pm 0.44\end{array}$ \\
\hline
\end{tabular}

Each value is the mean \pm s.e. of at least four experiments.

Significantly different from the result after bolus instillation $(* P<0.05$, **P $<0.01$, *** $P<$ 0.001). 
Figure 1

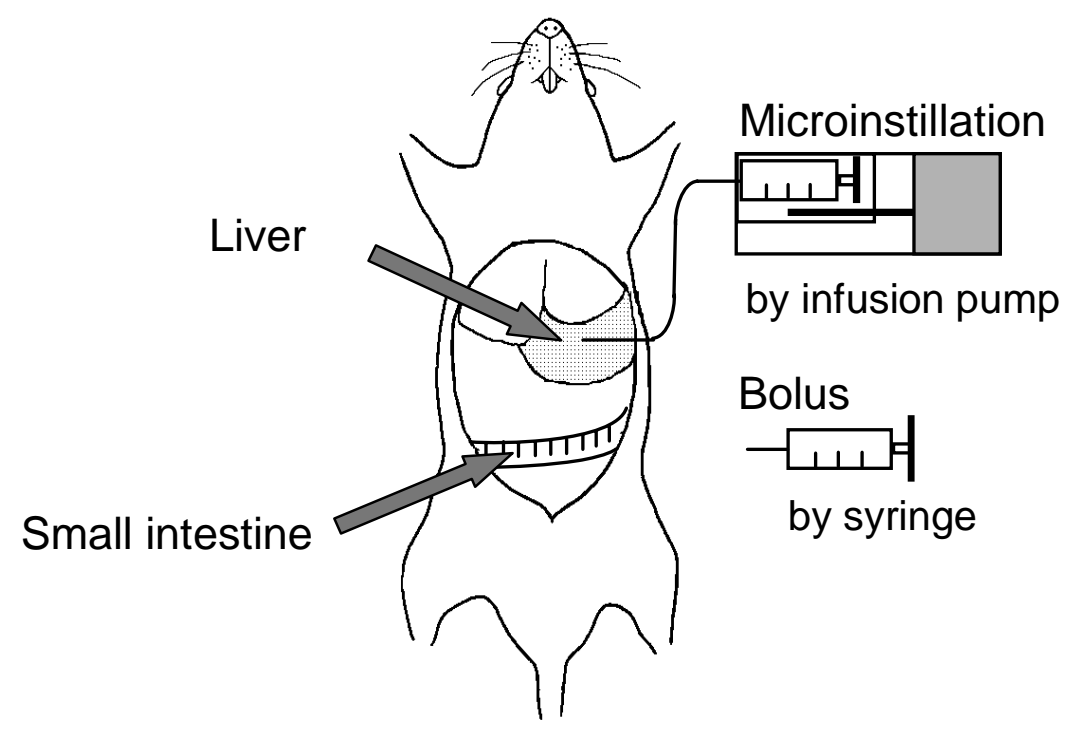


Figure 2

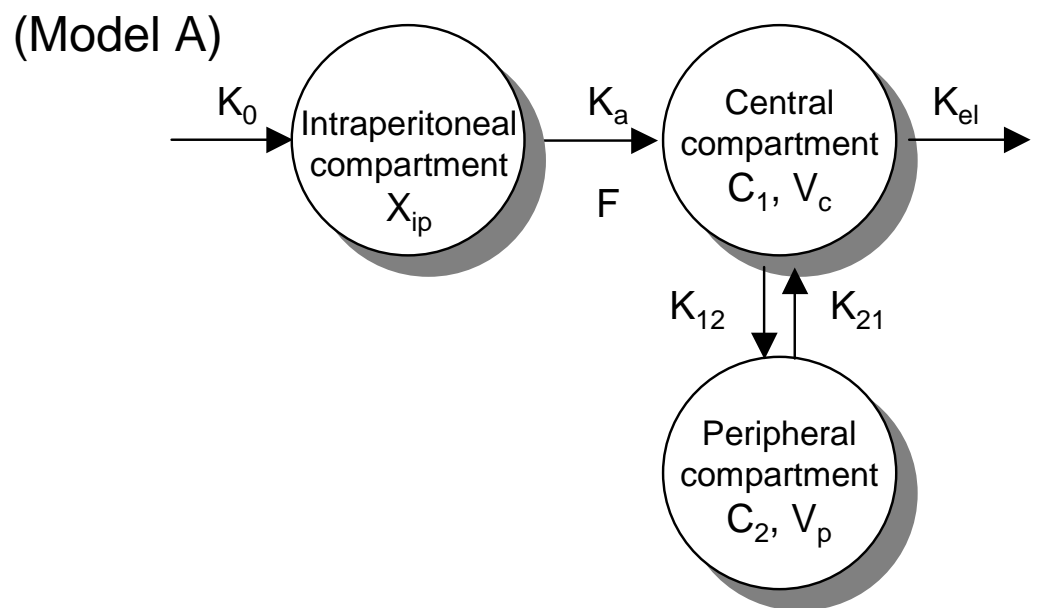

(Model B)

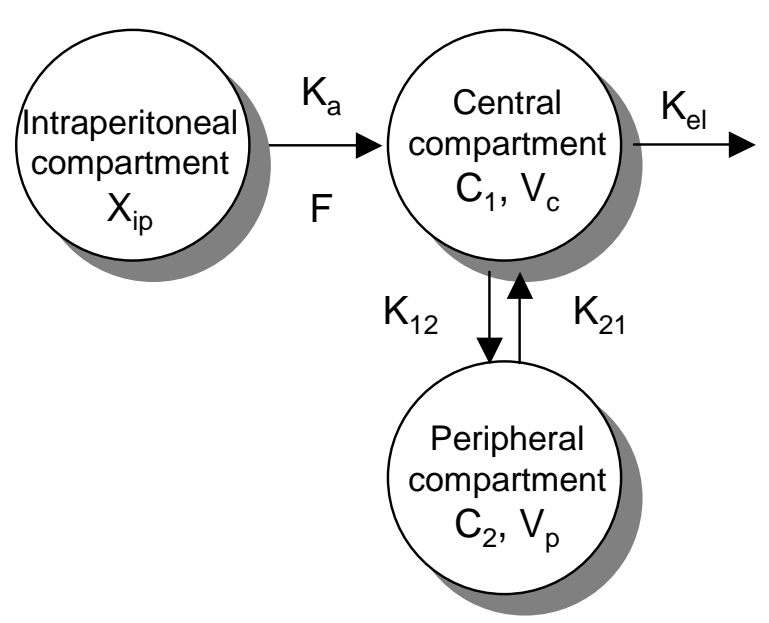


Figure 3

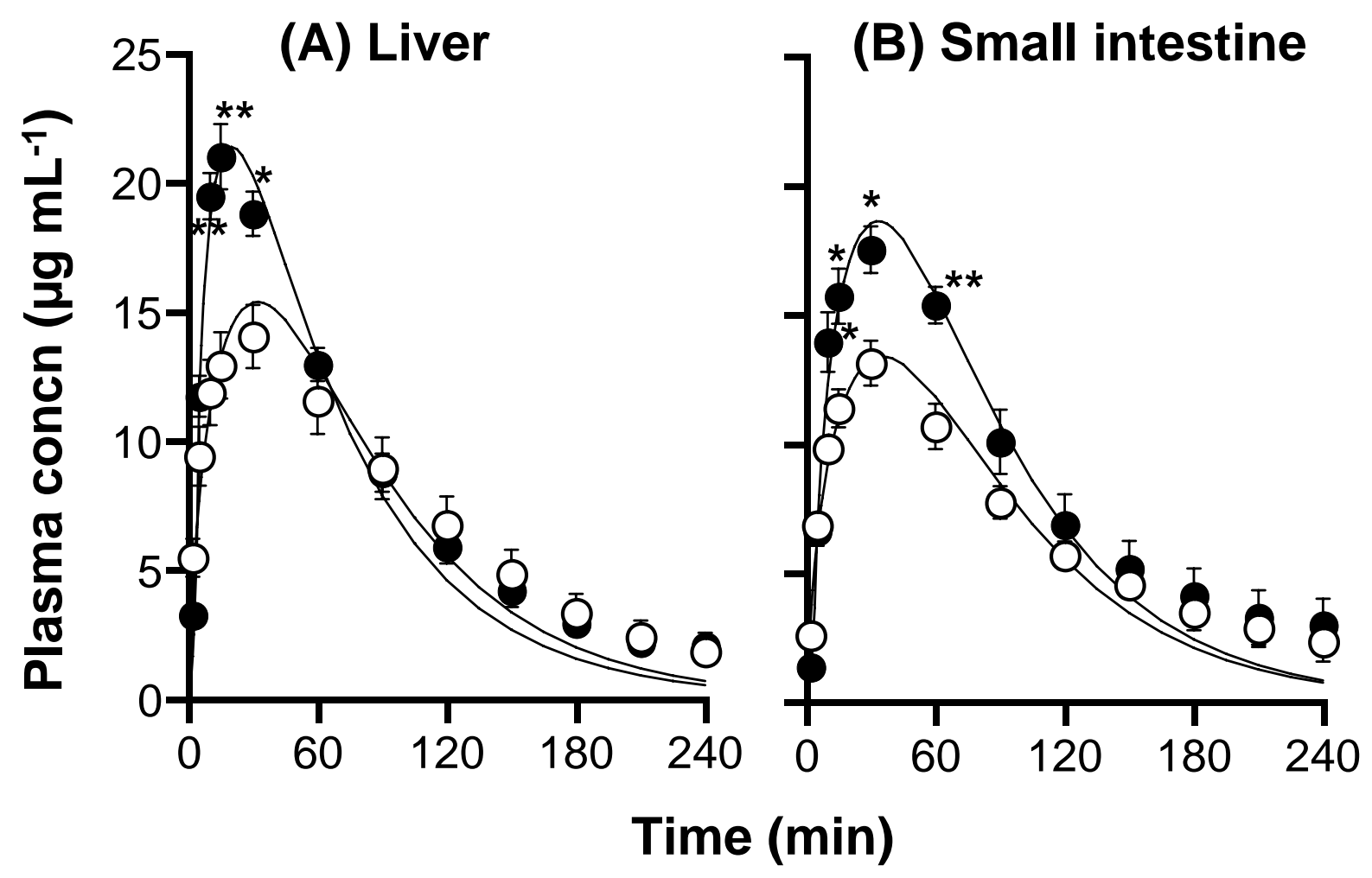


Figure 4

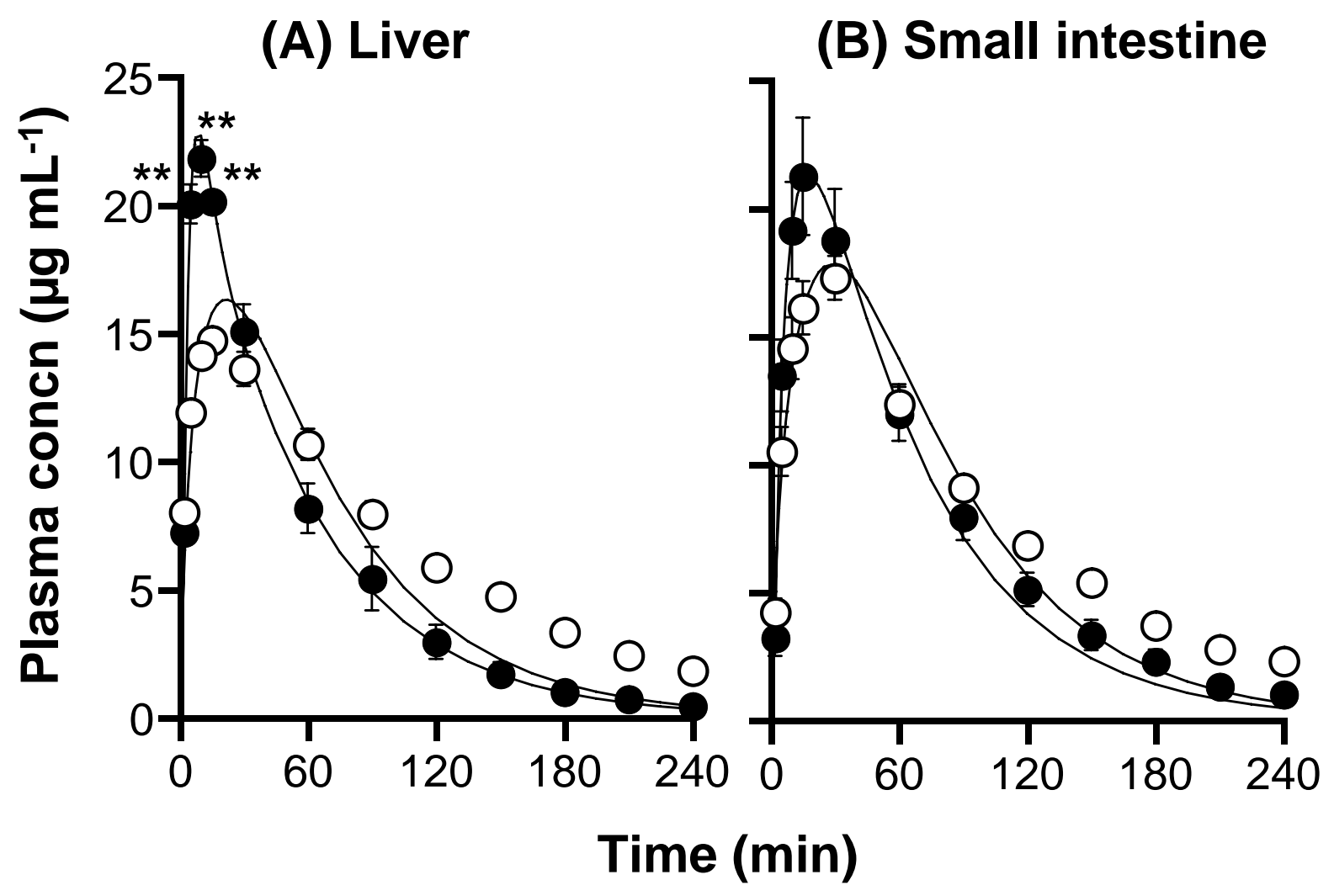

